\section{Ada and the engines}

\section{Richard Gregory}

Ada: A Life and a Legacy. By Dorothy Stein. MIT Press:1985. Pp.321. \$19.95, $£ 17.50$.

ADA, daughter of Byron, was born in 1815. Her mother, Annabella Milbanke, left Byron, who himself left England the following year - never to see his offspring again. In 1835 Ada married Lord King, who became the Earl and she the Countess of Lovelace in 1838.

Five years earlier, in 1833 (not long, incidentally, before she attempted to elope with her still unidentified tutor) Ada had first met Charles Babbage. They formed a lasting friendship in which she worked with and for him in the development of the first computers: the Difference Engine for computing tables and the general-purpose programmable Analytical Engine, which was never completed. It is for her association with Babbage that Ada is principally remembered, to the extent that she is said to have been the world's first computer programmer.

In her rich study of human drama and social history at the birth of the modern world, Dorothy Stein gives due accord to Ada's organizing abilities and her work in

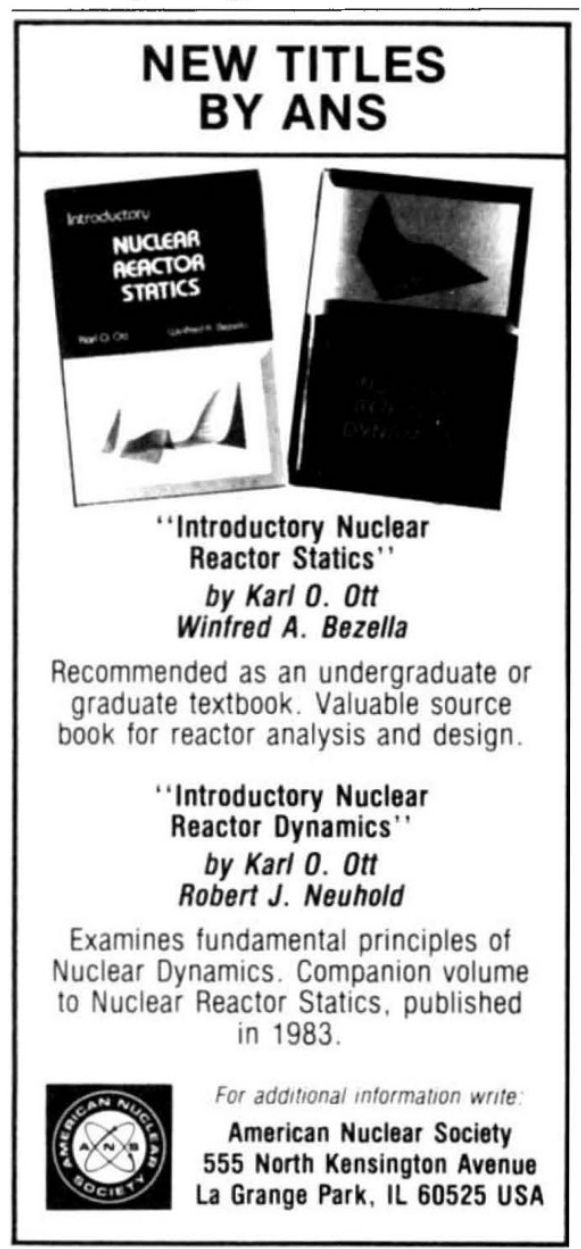

Reader Service No.22 translating and adding to Menabrea's monograph on the calculating engines. She does not, however, regard her as a major originator. The key historical questions revolve around the use of Jacquard punched cards to program the Analytical Engine. Dorothy Stein writes (p.93):

For the modern reader the important distinction . . . is that the Difference Engine followed an unvarying computational path (except for the parlour games Babbage played for the benefit of visitors such as Lady Byron), while the Analytical Engine was to be truly programmable and capable of changing its path according to the results of intermediate calculations or processes. Yet this was a feature mentioned by Ada only in passing . . . . For Ada - as for Babbage - the calculating machine was a metaphor as well as a harbinger of economic and scientific progress. For example, the theme stressed in presenting the 'illustrations' or programs was that they demonstrate how certain lengthy, laborious, and complex calculations can be most efficiently executed ... . by the machine into recurrent cyclical groups. The same set of operations can then be repeated over and over by the engine, with only the starting and stopping points indicated by the instructions.

Ada, it seems, saw the programs, and her own hard-won knowledge and skills, in contemporary economic terms as capital to save labour and increase enterprise. But this interpretation hardly reduces her achievement: she clearly made a notable contribution to the working out of Babbage's ideas and to what at that time was (and perhaps still is) the metaphysics of computing, asking such questions as: "How can a machine handle imaginary

\section{Glycans explored}

\section{Tim Hardingham}

Glycoprotein and Proteoglycan Techniques. By J.G. Beeley. Elsevier: 1985. Pp. 462. Hbk Dfl. 295, \$109.25; pbk Dfl. 85, $\$ 31.50$.

CARBOHYDRATE structures can be one of the great turn-offs of student days. Be that as it may, the rise in interest in all aspects of the biological functions of glycoproteins and proteoglycans means that there is an ever-widening audience of people keen to get to grips with them. This book does much to help, for not only does it provide a compendium of useful laboratory techniques but also succeeds in conveying some of the essential flavour of research in this area; it gives a good, broad perspective on the variable and yet ordered structures shown by glycoproteins and proteoglycans, and a thorough chemical overview of what can and cannot be done to the intact glycoproteins and their isolated glycopeptides.

The early sections deal with largely tra-

\section{IMAGE \\ UNAVAILABLE FOR COPYRIGHT REASONS}

\section{The young Ada - " gifted with intense imagination".}

numbers?". It appears, though, that Babbage (born in 1792) was generally a couple of decades ahead of her in questions and answers, and infinitely ahead of everyone else. He himself remains a shadowy but dominating figure in Dorothy Stein's account.

Ada comes remarkably alive in this book, passionate but at times neurotic, with almost too much self-awareness, and falling into disasters ranging from illness and accident to losses on the horses - all this is wonderfully preserved in her correspondence and is most ably presented here. She was gifted with intense imagination. But she had but intermittent perseverance, even for bringing into being the calculating engines she had the wit to see were to be of such immense significance. $\square$

Richard Gregory is a Professor in the Brain and Perception Laboratory of the Department of Anatomy, Medical School, University of Bris. tol, University Walk, Bristol BS81TD, UK.

ditional chemical methods of structural analysis. It is, however, the later parts, which review the use of specific enzymes and include sections on the battery of approaches possible with lectins and radioactive labelling techniques, that will be particularly useful. The range covered includes good examples of the variety of approaches that are possible for isolation, purification and structural analysis. Here, too, the author also addresses some of the problems frequently encountered when the supply of starting material is limited, as in characterizing products from cell culture.

The content is not beyond criticism some of the newer approaches are not mentioned - but the emphasis on techniques accessible to any reasonably equipped laboratory means that the book will be ideal for those just starting up. Moreover it should enable both experienced and inexperienced readers to assimilate with much greater insight the wealth of current publications in this field.

Tim Hardingham is Deputy Head of the Division of Biochemistry, Kennedy Institute of Rheumatology, Hammersmith, London W6 $7 D W, U K$ 